\title{
Short Communication: The ecological and economic values of secondary forest on abandoned land in Samarinda, East Kalimantan Province, Indonesia
}

\author{
KARMINI ${ }^{1, v}$, KARYATI $^{2, v v}$, KUSNO YULI WIDIATI ${ }^{2}$ \\ ${ }^{1}$ Faculty of Agriculture, Universitas Mulawarman. Jl. Pasir Balengkong, Kampus Gunung Kelua, Samarinda 75123, East Kalimantan, Indonesia. \\ Tel.: +62-541-749161, Fax.: +62-541-738341, `email: karmini @ faperta.unmul.ac.id \\ ${ }^{2}$ Faculty of Forestry, Universitas Mulawarman. J1. Ki Hajar Dewantara, Kampus Gunung Kelua, Samarinda 75123, East Kalimantan, Indonesia. \\ Tel.: +62-541-735089, 749068, Fax.: +62-541-735379, ^^email: karyati@fahutan.unmul.ac.id
}

Manuscript received: 14 October 2020. Revision accepted: 31 October 2020.

\begin{abstract}
Karmini, Karyati, Widiati KY. 2020. Short Communication: The ecological and economic values of secondary forest on abandoned land in Samarinda, East Kalimantan Province, Indonesia. Biodiversitas 21: 5550-5558. There is a large area of abandoned land in East Kalimantan Province. These abandoned traditional gardens which have been neglected for a long time have important ecological and economic values. This study aimed to assess the ecological and economic values of secondary forest on abandoned land in Samarinda, East Kalimantan Province. The ecological aspects assessed were stand structure, floristic composition, and species diversity. Meanwhile, the economic aspects analyzed were log price, harvesting cost, profit margin, and stumpage value. The vegetation survey was carried out on all trees with a diameter at breast height $(\mathrm{DBH}) \geq 5 \mathrm{~cm}$ in 10 subplots, each measuring $20 \mathrm{~m} \times 20 \mathrm{~m}$. A total of 192 trees were recorded, belonging to 29 species, 19 genera and 17 families. The most dominant species were Macaranga triloba (Importance Value, IV of 46.16), Macaranga tanarius (IV of 22.97), and Nephelium lappaceum (IV of 20.94). The indexes of diversity, dominance, evenness, and richness in the studied plots were $1.33,0.06,0.40$, and 5.33, respectively. The means of wood price, logging cost, profit margin, and stumpage value of the secondary forest were USD199.55 m-3, USD69.01 m ${ }^{-3}$, USD25.45 m ${ }^{-3}$, and USD51.56 ha${ }^{1}$, respectively. This study confirmed that the abandoned land had high ecological and economic values.
\end{abstract}

Keywords: Abandoned land, diversity, fallow land, stumpage value, tropic

\section{INTRODUCTION}

In East Kalimantan Province there is about 3 million hectares of abandoned land, consisting mainly of former coal mining land and fallow land of the shifting cultivation system which is no longer cultivated by the owners. The indigenous Dayak tribe usually replanted the land after rice harvesting with multipurpose species, such as fruit trees, rattan, and bamboo. Over time, the abandoned land will turn into secondary forest due to succession. After decades, the species richness and composition in the regrowth forests can approach old forest which can serve as biodiversity repositories (Karyati et al. 2018; Yirdaw et al. 2019).

The time required for vegetation recovery to original forest characteristics is influenced by several factors such as type of land use, cycle duration, and size of cleared patches (Aththorick et al. 2012). The pioneer plant species dominate abandoned land indicated by an intermediate diversity, a low dominance index, and a high evenness index (Karmini et al. 2020; Karyati et al. 2013; Karyati et al. 2018). The rate of succession and thus the restoration of soil on abandoned land can be accelerated through plantation programs. These activities can reduce the expansion of forest conversion into cultivated areas (Klanderud et al. 2010).

Also, forest planting has an important role in providing ecological, economic, religious, and cultural functions of the secondary forest (Setiawan 2010). The average stumpage value in abandoned land was calculated to be
83.05 USD ha- ${ }^{-1}$ and the total value 2,159.36 USD ha ${ }^{-1}$ (Karmini et al. 2020).

The calculation of the potential economic value of timber and non-timber forest products that can be used as onstruction materials for buildings or furniture will illustrate the potential income that might be achieved from managing abandoned land. Most of the previous studies reported information on the ecological and economic value of abandoned lands separately. The previous similar study reported the ecological and economic value of abandoned land where the previous land use was shifting cultivation (Karmini et al. 2020). However, study that provides comprehensive information on the ecological and economic value of abandoned land after being used as traditional gardens in the tropics is still very limited. The objectives of the study were to assess the ecological and economic values of secondary forest on abandoned land. The findings are expected to be used as the basis to make recommendation in managing the abandoned land in East Kalimantan and in other tropical areas.

\section{MATERIALS AND METHODS}

\section{Study site}

The research was carried out on a land area of abandoned traditional garden in Bukit Pinang area, in Samarinda Ulu Subdistrict, Samarinda City, East 
Kalimantan Province, Indonesia. The research plot is located on land which is a traditional garden that has been left for more than 44 years based on land owner confirmation. The previous similar land use type of traditional gardening on this land was also reported based on interviews with land owners. The boundaries of the area are Kutai Kartanegara district at north, Samarinda Utara district at east, Air Putih Subdistrict at south, and Sungai Kunjang district at west. Samarinda City is the capital of East Kalimantan Province, Indonesia and the city with the largest population in the entire island of Kalimantan. The population of Samarinda is 812,597 people. Samarinda has an area of $718 \mathrm{~km}^{2}$ with a hilly geographical condition with altitudes varying from 10 to 200 meters above sea level. Samarinda City is divided by Mahakan river and becomes the gateway to the area around by river, land, and air. The research plot lies at the coordinate points of $0^{\circ} 25^{\prime} 32.8^{\prime \prime} \mathrm{S}$ $117^{\circ} 05^{\prime} 56.8^{\prime \prime} \mathrm{E}$ (Figure 1).

\section{Procedures}

\section{Data collection}

The vegetation survey was conducted from March to September 2020. A total of 10 subplots, each measuring 20 $\mathrm{m} \times 20 \mathrm{~m}$, were established in the study site (Fachrul 2007; Kusmana 2017). Sub plots were established within the same abandoned land. All woody trees with a diameter at breast height $(\mathrm{DBH})$ of $\geq 5 \mathrm{~cm}$ were measured for diameter and height, and their species were identified. The secondary data were obtained from reports and articles from previous researches (Forestry Department of Peninsular Malaysia (FDPM) (1997); Hanum et al. 2001; Noor et al. 1992; Noor and Shahwahid 1999).

\section{Data analysis}

Ecological characteristics

The following formulas were used to measure individual basal area (BA) and volume (V) (Husch et al. 1982):

Individuals $\mathrm{BA}=\pi(\mathrm{DBH} / 2)^{2} .10^{-4}$

Individuals $\mathrm{V}=1 / 4 \pi \times \mathrm{DBH}^{2} .10^{-4} \times \mathrm{H} \times f$

Where: DBH is diameter at breast height $(\mathrm{cm})$, ' $\mathrm{H}$ ' is tree height $(\mathrm{m})$, and ' $f$ ' 'is form factor.

The importance value index (IVi) was used to determine the dominant species of community within the studied plots in (Fachrul 2007):

$\mathrm{RF}=($ Frequency of a species/Total of frequencies of all species $) \times 100$

$\mathrm{Rd}=$ (The number of individual of a species/Total number of individuals $) \times 100$

$\mathrm{RD}=($ Total basal area for a species/Total basal area for all species) $\times 100$

$\mathrm{IVi}=\mathrm{RF}+\mathrm{Rd}+\mathrm{RD}$

Where: $\mathrm{RF}$ is relative frequency, $\mathrm{Rd}$ is relative density, and $\mathrm{RD}$ is relative dominance.
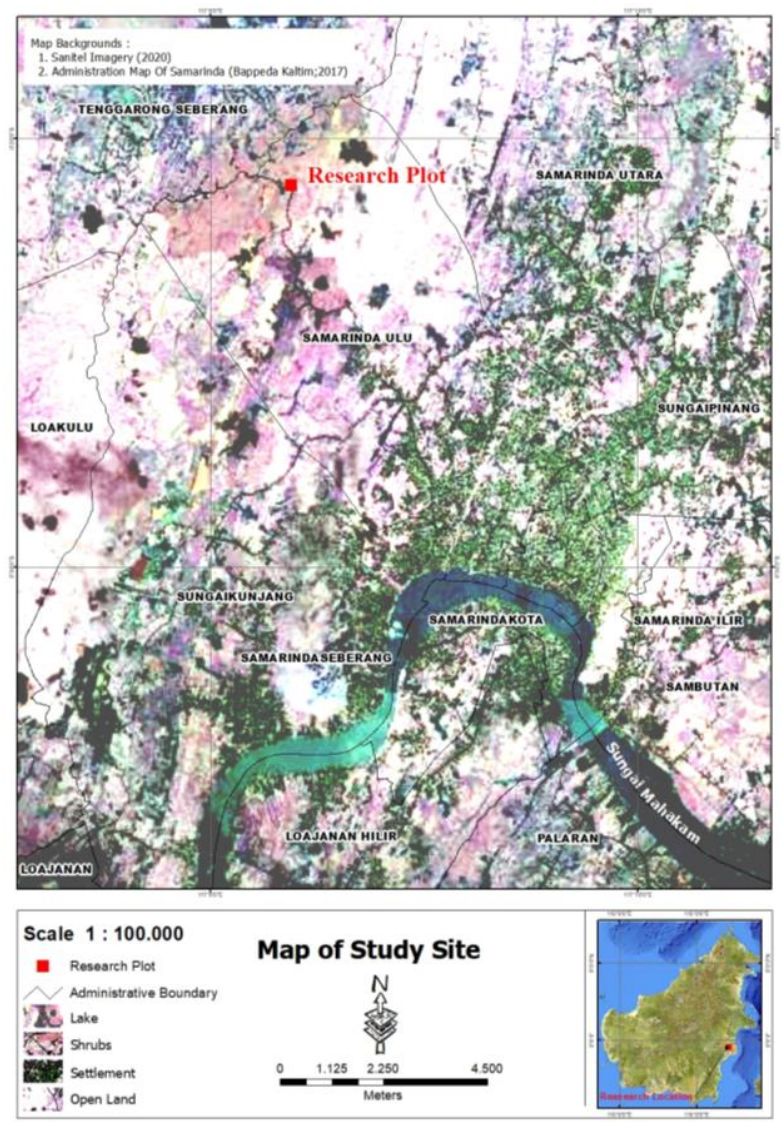

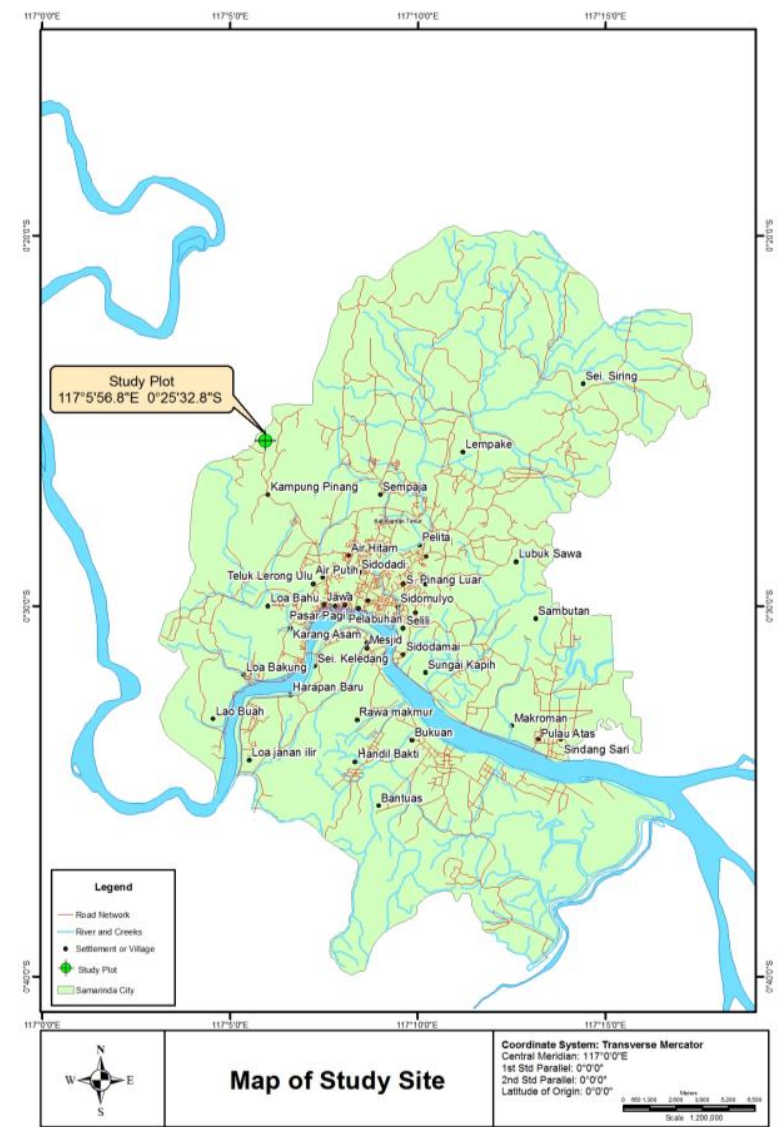

Figure 1. Map of study site in Bukit Pinang area, in Samarinda Ulu Subdistrict, Samarinda City, East Kalimantan Province, Indonesia 
The four diversity indices were analyzed to describe species diversity of standing trees in the studied plots. These diversity indices were Shannon-Wiener's diversity index $\left(H^{\prime}\right)$, Simpson's dominance index $\left(D_{s}\right)$, Pielou's evenness index $\left(J^{\prime}\right)$, and Margalef's richness index $(R)$ (Odum and Barrett 2005):

$$
\begin{aligned}
& H^{\prime}=-\sum_{i=1}^{s}\left(\frac{n_{i}}{N}\right) \ln \left(\frac{n_{i}}{N}\right) \\
& D_{s}=\sum_{i=1}^{s}\left(\frac{n_{i}}{N}\right)^{2} \\
& J^{\prime}=\frac{H^{\prime}}{\ln (S)} \\
& R=\frac{(S-1)}{\ln n}
\end{aligned}
$$

Where: $\mathrm{n}_{\mathrm{i}}$ : number of individuals of the $i$ - th species, $\mathrm{N}$ : total number of all the individuals in a unit area, and $S$ : number of species in each plot.

\section{Economic literature}

Data in Table 1 shows number of logs that produced from tree diameter up to $75 \mathrm{~cm}$. Based on diameter class and number of logs, the equivalent merchantable height was determined.

Reduction factor of log price was determined based on size class of DBH (Table 2). This research used assumption that the reduction factor of log price with size class of $\mathrm{DBH}$ $<15 \mathrm{~cm}$ was 0.6 .

Profit ratio was fixed at $30 \%$ according to Noor and Shahwahid (1999).

Equation of profit margin was calculated as follows (Noor and Shahwahid 1999):

Table 1. Merchantable tree heights

\begin{tabular}{ccc}
\hline $\begin{array}{c}\text { Diameter class } \\
(\mathbf{c m})\end{array}$ & $\begin{array}{c}\text { Number of logs }(\mathbf{5} \mathbf{~ m} \\
\text { long) }\end{array}$ & $\begin{array}{c}\text { Equivalent } \\
\text { merchantable height } \\
(\mathbf{m})\end{array}$ \\
\hline$<15$ & 0.5 & $2.5^{*}$ \\
$15-30$ & 1 & 5 \\
$+30-60$ & 2 & 10 \\
$+60-75$ & 3 & 15 \\
75 ke atas & 4 & 20 \\
\hline
\end{tabular}

Note: *Analyzed data; FDPM (Forestry Department of Peninsular Malaysia) (1997)

Table 2. Reduction factor of $\log$ price

\begin{tabular}{cc}
\hline DBH size class $(\mathbf{c m})$ & Reduction factor \\
\hline$<15$ & $0.60^{*}$ \\
$15-29$ & 0.45 \\
$30-44$ & 0.30 \\
$45-49$ & 0.15 \\
$50-54$ & 0.025 \\
$\geq 55$ & 0.00 \\
\hline
\end{tabular}

Note: *Analyzed data; Noor et al. (1992) and Hanum et al. (2001)

$$
P M_{i j}=\sum_{i=1}^{n} \sum_{j=1}^{k}\left(P_{i j} x P R\right) /(1+P R)
$$

Where:

$P M_{i j}$ : profit margin;

$P_{i j}: \log$ price for each species at sawmill and diameter class:

$P R$ : profit ratio;

$i \quad:$ an index for each species $(\mathrm{i}=1,2,3,4, \ldots ., \mathrm{n})$;

$j \quad$ : an index for diameter class $(\mathrm{i}=1,2,3,4, \ldots, \mathrm{n})$.

Logging cost of all species was USD68.03 $\mathrm{m}^{-3}$ (except logging cost of Eusideroxylon zwageri was USD102.04 m3 ) in research location when the research was done. The exchange rate of 1 USD was 14,740 IDR on 8 October 2020. The equation of stumpage values is presented below:

$$
S_{i j}=\sum_{i=1}^{n} \sum_{j=1}^{k} V_{i j}\left(P_{i j}+C+P M\right)
$$

Where:

$S_{i j}$ : stumpage value for each species and diameter class (USD ha-1);

$V_{i j} \quad$ : volume of timber for each species and diameter class $\left(\mathrm{m}^{3}\right)$;

$P_{i j}: \log$ price for each species at sawmill and diameter class (USD m ${ }^{-3}$ );

$C \quad$ : average logging cost $\left(\mathrm{USD} \mathrm{ha}^{-1}\right)$;

$P M_{i j}$ : profit margin (USD m $\left.{ }^{-3}\right)$;

$i \quad:$ an index for each species $(\mathrm{i}=1,2,3,4, \ldots, \mathrm{n})$;

$j \quad:$ an index for diameter class $(\mathrm{i}=1,2,3,4, \ldots ., \mathrm{n})$.

\section{RESULTS AND DISCUSSION}

\section{Ecological characteristics}

Diameter at Breast Height (DBH) and height distributions

The diameter distribution in the research plots shows an inverted $\mathbf{J}$ shape where an increase in diameter class is followed by a decrease in the number of trees (Figure 2). The number of trees in the DBH class of $5.0-15.0 \mathrm{~cm}$ was $134(70 \%)$, the DBH class of $15.1-25.0 \mathrm{~cm} 32(17 \%)$, the DBH class of $25.1-35.0 \mathrm{~cm} 20(10 \%)$, and the DBH class of $>35.0 \mathrm{~cm} 6(3 \%)$. Meanwhile, most of the trees $(59 \%)$ belong to the $5-10 \mathrm{~cm}$ height class (Figure 3 ). The tree heights were distributed in height classes of 0.0-5.0 $\mathrm{m}(9$ trees or 5\%), 5.1-10.0 m (114 trees or 59\%), 10.1-15.0 m (53 trees or $28 \%)$, and $>15 \mathrm{~m}$ (16 trees or $8 \%$ ). In general, the diameter distribution of trees in secondary forest has an inverted J-shape (Feldpausch et al. 2007; Álvarez-Yépiz et al. 2008) while the distribution of height class is slightly positively skewed (Ohtsuka 1999). The similar trends in trees diameter class and height class were also reported on abandoned land after cultivation (Karmini et al. 2020).

\section{Density, basal area, and volume}

The number of individuals recorded in the research plots was 192 trees, belonging to 29 species, 19 genera, and 17 families. There were 8 tree species of Moraceae, 5 tree species of Euphorbiaceae, 3 tree species of Anacardiaceae, 
and 2 tree species of Phyllanthaceae. Each of the other 11 families consisted of 1 tree species. The density, basal area, and volume of species in the study site are presented in Table 3. The DBH of trees in the study plots ranged from $6.4 \mathrm{~cm}$ to $29.1 \mathrm{~cm}$ with an average $\mathrm{DBH}$ of $16.3 \mathrm{~cm}$. Meanwhile, the tree height ranged from $6.0 \mathrm{~m}$ to $17.4 \mathrm{~m}$ with an average height of $10.4 \mathrm{~m}$. The total BA and volume of trees in the study plot were 9.44 and 76.86 , respectively. These values are smaller than the total BA (9.75) and the total volume (91.97) in abandoned land after cultivation (Karmini et al. 2020).

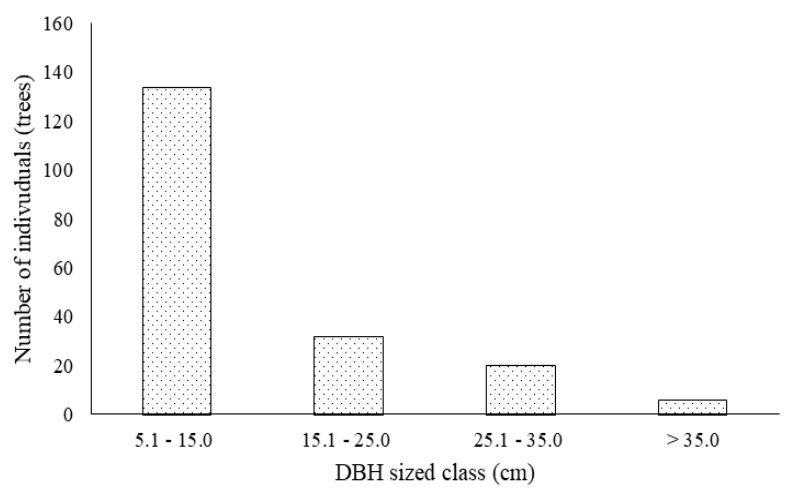

Figure 2. Distribution of diameter at breast height (DBH) in 0.4 ha at the study plot

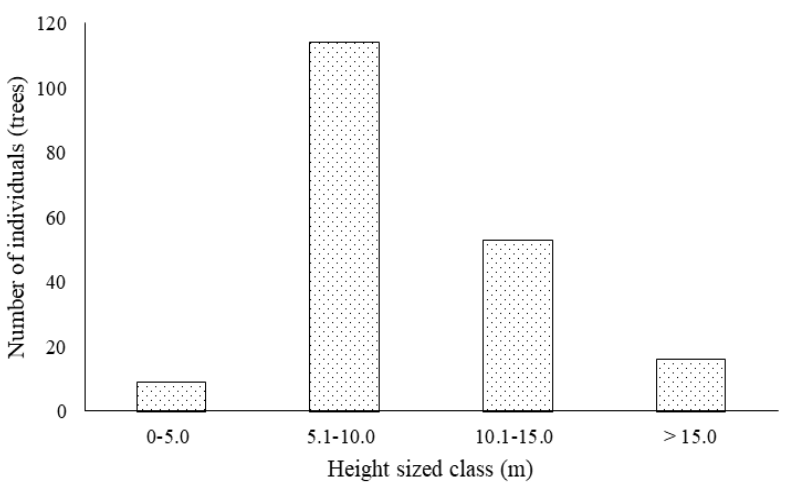

Figure 3. Distribution of height in 0.4 ha at the study plot

Table 3. Density, basal area, and volume of species (DBH of $\geq 5 \mathrm{~cm}$ ) in the study plots

\begin{tabular}{|c|c|c|c|c|c|c|}
\hline Species & Family & $\mathbf{N}$ & $\begin{array}{c}\text { Average of DBH } \\
(\mathrm{cm})\end{array}$ & $\begin{array}{c}\text { Average of height } \\
\text { (m) }\end{array}$ & $\begin{array}{c}\text { Total of BA } \\
\left(\mathbf{m}^{2} \mathbf{h a}^{-1}\right)\end{array}$ & $\begin{array}{c}\text { Total volume } \\
\left(\mathbf{m}^{3} \mathbf{h a}^{-1}\right)\end{array}$ \\
\hline Macaranga tanarius & Euphorbiaceae & 13 & 18.3 & 12.0 & 0.91 & 7.86 \\
\hline Mangifera indica & Anacardiaceae & 4 & 29.1 & 17.4 & 0.67 & 7.49 \\
\hline Nephelium lappaceum & Sapindaceae & 12 & 15.0 & 9.5 & 0.77 & 6.37 \\
\hline Macaranga triloba & Euphorbiaceae & 48 & 9.7 & 8.7 & 1.00 & 6.05 \\
\hline Artocarpus integer & Moraceae & 4 & 26.4 & 14.0 & 0.62 & 5.63 \\
\hline Trema orientalis & Cannabaceae & 8 & 16.6 & 13.8 & 0.51 & 5.51 \\
\hline Artocarpus dadah & Moraceae & 3 & 28.2 & 15.5 & 0.47 & 4.74 \\
\hline Artocarpus anisophyllus & Moraceae & 9 & 14.1 & 9.5 & 0.48 & 4.70 \\
\hline Vernonia arborea & Asteraceae & 4 & 23.6 & 12.1 & 0.46 & 3.69 \\
\hline Artocarpus odoratissimus & Moraceae & 5 & 21.2 & 9.6 & 0.48 & 3.22 \\
\hline Homalanthus populneus & Euphorbiaceae & 7 & 12.4 & 8.2 & 0.35 & 2.69 \\
\hline Mallotus paniculatus & Euphorbiaceae & 15 & 9.8 & 8.4 & 0.33 & 2.21 \\
\hline Artocarpus tamaran & Moraceae & 2 & 22.0 & 11.5 & 0.23 & 2.06 \\
\hline Ficus uncinata & Moraceae & 16 & 10.2 & 8.5 & 0.35 & 2.01 \\
\hline Symplocos fasciculata & Symplocaceae & 5 & 16.5 & 7.1 & 0.31 & 1.74 \\
\hline Durio zibethinus & Malvaceae & 2 & 15.2 & 12.4 & 0.13 & 1.49 \\
\hline Macaranga gigantea & Euphorbiaceae & 2 & 18.9 & 9.8 & 0.19 & 1.43 \\
\hline Artocarpus elasticus & Moraceae & 4 & 15.2 & 8.4 & 0.23 & 1.43 \\
\hline Archidendron pauciflorum & Fabaceae & 10 & 9.5 & 8.7 & 0.19 & 1.19 \\
\hline Glochidion obscurum & Phyllanthaceae & 1 & 27.5 & 12.0 & 0.15 & 1.16 \\
\hline Baccaurea parvifolia & Phyllanthaceae & 2 & 17.0 & 14.0 & 0.11 & 1.05 \\
\hline Cratoxylum arborescens & Hypericaceae & 3 & 12.5 & 7.0 & 0.12 & 0.64 \\
\hline Oroxylum indicum & Bignoniaceae & 2 & 13.7 & 11.3 & 0.08 & 0.60 \\
\hline Couroupita guianensis & Lecythidaceae & 2 & 12.0 & 11.2 & 0.06 & 0.52 \\
\hline Artocarpus heterophyllus & Moraceae & 2 & 13.2 & 11.1 & 0.07 & 0.50 \\
\hline Mangifera sp. & Anacardiaceae & 1 & 18.5 & 10.0 & 0.07 & 0.44 \\
\hline Eusideroxylon zwageri & Lauraceae & 2 & 11.8 & 6.0 & 0.05 & 0.21 \\
\hline Alstonia scholaris & Apocynaceae & 3 & 7.9 & 7.4 & 0.04 & 0.20 \\
\hline Mangifera odorata & Anacardiaceae & 1 & 6.4 & 7.3 & 0.01 & 0.04 \\
\hline Total & & 192.0 & 472.5 & 302.3 & 9.44 & 76.86 \\
\hline Average & & 6.6 & 16.3 & 10.4 & 0.33 & 2.65 \\
\hline Minimum & & 1.0 & 6.4 & 6.0 & 0.01 & 0.04 \\
\hline Maximum & & 48.0 & 29.1 & 17.4 & 1.00 & 7.86 \\
\hline
\end{tabular}

Note: $\mathrm{N}$ : number of individuals (trees), DBH: diameter at breast height, BA: basal area 
The five dominant species based on total basal area and volume were Macaranga tanarius (total $\mathrm{BA}=0.91 \mathrm{~m}^{2} \mathrm{ha}^{-1}$ and volume $=7.86 \mathrm{~m}^{3} \mathrm{ha}^{-1}$ ), Mangifera indica (total $\mathrm{BA}=0.67 \mathrm{~m}^{2} \mathrm{ha}^{-1}$ and volume $\left.=7.49 \mathrm{~m}^{3} \mathrm{ha}^{-1}\right)$, Nephelium lappaceum (total $\mathrm{BA}=0.77 \mathrm{~m}^{2} \mathrm{ha}^{-1}$ and volume $=6.37 \mathrm{~m}^{3}$ ha ${ }^{1}$ ), Macaranga triloba (total $\mathrm{BA}=1.00 \mathrm{~m}^{2} \mathrm{ha}^{-1}$ and volume $=6.05 \mathrm{~m}^{3} \mathrm{ha}^{-1}$ ), and Artocarpus integer (total $\mathrm{BA}=0.62 \mathrm{~m}^{2} \mathrm{ha}^{-1}$ and volume $=5.63 \mathrm{~m}^{3} \mathrm{ha}^{-1}$ ). The common species in abandoned land were dominated by fast growing species, such as Macaranga spp. and Artocarpus spp. as also reported by Karyati et al. (2018) and Karmini et al. (2020). The recorded fruit trees showed that the studied plot was abandoned garden. These fruit species planted were Artocarpus anisophyllus (Mentawa), Artocarpus elasticus (Benda), Artocarpus heterophyllus (Nangka), Artocarpus integer (Cempedak), Artocarpus odoratissimus (Terap), Mangifera indica (Mangga), Mangifera odorata (Kuweni), Durio zibethinus (Durian), and Nephelium lappaceum (Rambutan). Artocarpus odoratissimus is a native tree species, while Artocarpus tamaran is an endemic tree species.

\section{Importance value index (IVi)}

Most of the dominant trees based on importance value index (IVi) were also dominant trees based on total BA and volume. The light demanding pioneer and fast growing species dominated the studied site (Table 4). The most dominant species in terms of IVi was Macaranga triloba (IVi of 46.16) followed by Macaranga triloba (IVi of 22.97), Nephelium lappaceum (IVi of 20.94), Ficus uncinata (IVi of 18.64), and Mallotus paniculatus (IVi of 17.93). Twelve of 29 species recorded had an IVi of more than 10.00 and 5 species of them had an IVi of 5.00-10.00. Meanwhile the other 12 species had an IVi of less than 5.00. Four dominant species of Euphorbiaceae (Macaranga triloba, Macaranga tanarius, Mallotus paniculatus, and Homalanthus populneus) reached a total IVi of 99.72. These four species were included in the 10 most dominant types based on IVi. Similar studies also reported that tree species from Euphorbiaceae were important and dominating tropical fallow lands (Karyati et al. 2018; Karmini et al. 2020). The total IVi of 8 species including Moraceae reached 84.75 . Moraceae was the family that had the most species in the research location.

Table 4. Importance value index (IVi) of trees $(\mathrm{DBH}$ of $>5 \mathrm{~cm}$ ) in 0.4 hectare of the study plots

\begin{tabular}{|c|c|c|c|c|c|}
\hline Species & Family & RF (\%) & $\operatorname{Rd}(\%)$ & RD (\%) & IVi $(\%)$ \\
\hline Macaranga triloba & Euphorbiaceae & 25.00 & 10.53 & 10.63 & 46.16 \\
\hline Macaranga tanarius & Euphorbiaceae & 6.77 & 6.58 & 9.62 & 22.97 \\
\hline Nephelium lappaceum & Sapindaceae & 6.25 & 6.58 & 8.11 & 20.94 \\
\hline Ficus uncinata & Moraceae & 8.33 & 6.58 & 3.72 & 18.64 \\
\hline Mallotus paniculatus & Euphorbiaceae & 7.81 & 6.58 & 3.54 & 17.93 \\
\hline Artocarpus anisophyllus & Moraceae & 4.69 & 6.58 & 5.11 & 16.37 \\
\hline Trema orientalis & Cannabaceae & 4.17 & 5.26 & 5.44 & 14.87 \\
\hline Artocarpus odoratissimus & Moraceae & 2.60 & 5.26 & 5.08 & 12.94 \\
\hline Homalanthus populneus & Euphorbiaceae & 3.65 & 5.26 & 3.75 & 12.66 \\
\hline Mangifera indica & Anacardiaceae & 2.08 & 2.63 & 7.05 & 11.77 \\
\hline Artocarpus integer & Moraceae & 2.08 & 2.63 & 6.57 & 11.28 \\
\hline Archidendron pauciflorum & Fabaceae & 5.21 & 3.95 & 2.07 & 11.22 \\
\hline Vernonia arborea & Asteraceae & 2.08 & 2.63 & 4.84 & 9.56 \\
\hline Artocarpus dadah & Moraceae & 1.56 & 2.63 & 4.99 & 9.19 \\
\hline Symplocos fasciculata & Symplocaceae & 2.60 & 2.63 & 3.28 & 8.51 \\
\hline Artocarpus elasticus & Moraceae & 2.08 & 2.63 & 2.46 & 7.18 \\
\hline Artocarpus tamaran & Moraceae & 1.04 & 2.63 & 2.39 & 6.06 \\
\hline Baccaurea parvifolia & Phyllanthaceae & 1.04 & 2.63 & 1.21 & 4.89 \\
\hline Macaranga gigantea & Euphorbiaceae & 1.04 & 1.32 & 1.99 & 4.35 \\
\hline Eusideroxylon zwageri & Lauraceae & 1.04 & 2.63 & 0.58 & 4.25 \\
\hline Cratoxylum arborescens & Hypericaceae & 1.56 & 1.32 & 1.23 & 4.10 \\
\hline Durio zibethinus & Malvaceae & 1.04 & 1.32 & 1.37 & 3.73 \\
\hline Glochidion obscurum & Phyllanthaceae & 0.52 & 1.32 & 1.58 & 3.41 \\
\hline Alstonia scholaris & Apocynaceae & 1.56 & 1.32 & 0.41 & 3.29 \\
\hline Oroxylum indicum & Bignoniaceae & 1.04 & 1.32 & 0.81 & 3.16 \\
\hline Artocarpus heterophyllus & Moraceae & 1.04 & 1.32 & 0.73 & 3.09 \\
\hline Couroupita guianensis & Lecythidaceae & 1.04 & 1.32 & 0.66 & 3.02 \\
\hline Mangifera sp. & Anacardiaceae & 0.52 & 1.32 & 0.71 & 2.55 \\
\hline Mangifera odorata & Anacardiaceae & 0.52 & 1.32 & 0.09 & 1.92 \\
\hline Total & & 100 & 100 & 100 & 300 \\
\hline
\end{tabular}

Note: RF: relative frequency, Rd: relative density, RD: relative dominance, IVI: importance value index. 


\section{Species diversity}

The tree diversity index was categorized as 'intermediate' ( $H^{\prime}$ of 1.33), indicating that there was a sufficient number of trees growing at the research location (Table 5). A very complex community is indicated by a high diversity of species (Brower et al. 1990). Meanwhile, the dominance index was at low criteria with a $D$ s value of 0.06. A low dominance value indicates that no species is dominant in the region. The evenness index was in the high category ( $J$ ' value of 0.91$)$, meaning that the individuals of trees in the studied plots were evenly distributed among species. A species richness index of 5.33 showed that high number of tree species existing in the study site. There were 192 trees included in 29 tree species recorded in the studied plots. Species richness is calculated based on the number of species in an area (Krebs, 2001). The results show that high diversity $\left(\mathrm{H}^{\prime}\right)$, evenness $\left(\mathrm{J}^{\prime}\right)$, and wealth $(\mathrm{R})$ will lead to low dominance (Ds). The similar results were reported for the diversity indices for trees with $\mathrm{DBH}$ of $>5$ $\mathrm{cm}$ on plots with an abandoned field age of 5, 10, 20 years (Karyati et al. 2018) and on abandoned land after shifting cultivation (Karmini et al. 2020).

\section{Economic value}

Log price

This research found 7 trees species with higher log prices than the other 22 tree spesies (Table 6). Their log prices were in the range from USD122.12 $\mathrm{m}^{-3}$ to USD651.29 $\mathrm{m}^{-3}$. The $\log$ price varies depending on the species and diameter class of log (Karmini et al. 2020). Eusideroxylon zwageri had the highest price, i.e., USD1,085.48 $\mathrm{m}^{-3}$. The timber price is positively correlated with its demand in society. Eusideroxylon zwageri has good quality of wood, and people like to use this wood for contruction materials.

Table 5. Diversity indices of trees with $\mathrm{DBH}$ of $\geq 5 \mathrm{~cm}$ in the study plots

\begin{tabular}{lc}
\hline \multicolumn{1}{c}{ Diversity indices } & Value \\
\hline Shannon-Wiener diversity index $\left(H^{\prime}\right)$ & 1.33 \\
Simpson dominance index $\left(D_{s}\right)$ & 0.06 \\
Pielou evenness index $\left(J^{\prime}\right)$ & 0.91 \\
Margalef species richness $(R)$ & 5.33 \\
\hline
\end{tabular}

Table 6. Number of stems, log price, and wood price at the study site

\begin{tabular}{|c|c|c|c|c|}
\hline Species & Family & $\begin{array}{c}\text { Number } \\
\left(\text { stems ha }^{-1}\right)\end{array}$ & $\begin{array}{l}\text { Log price } \\
\left(\text { USD m}^{-3}\right)\end{array}$ & $\begin{array}{c}\text { Timber price } \\
\left(\mathrm{USD} \mathbf{~ m}^{-3}\right)\end{array}$ \\
\hline Eusideroxylon zwageri & Lauraceae & 8 & 651.29 & $1,085.48$ \\
\hline Alstonia scholaris & Apocynaceae & 13 & 488.47 & 814.11 \\
\hline Artocarpus anisophyllus & Moraceae & 38 & 447.76 & 814.11 \\
\hline Oroxylum indicum & Bignoniaceae & 8 & 427.41 & 814.11 \\
\hline Durio zibethinus & Malvaceae & 8 & 151.37 & 288.33 \\
\hline Cratoxylum arborescens & Hypericaceae & 13 & 130.60 & 237.45 \\
\hline Artocarpus elasticus & Moraceae & 17 & 74.80 & 142.47 \\
\hline Artocarpus dadah & Moraceae & 13 & 64.11 & 142.47 \\
\hline Archidendron pauciflorum & Fabaceae & 42 & 79.38 & 135.69 \\
\hline Nephelium lappaceum & Sapindaceae & 50 & 64.11 & 122.12 \\
\hline Baccaurea parvifolia & Phyllanthaceae & 8 & 54.95 & 122.12 \\
\hline Mangifera odorata & Anacardiaceae & 4 & 30.53 & 50.88 \\
\hline Macaranga triloba & Euphorbiaceae & 200 & 30.37 & 50.88 \\
\hline Mallotus paniculatus & Euphorbiaceae & 63 & 29.51 & 50.88 \\
\hline Homalanthus populneus & Euphorbiaceae & 29 & 28.35 & 50.88 \\
\hline Symplocos fasciculata & Symplocaceae & 21 & 27.48 & 50.88 \\
\hline Couroupita guianensis & Lecythidaceae & 8 & 26.71 & 50.88 \\
\hline Trema orientalis & Cannabaceae & 33 & 26.71 & 50.88 \\
\hline Macaranga gigantea & Euphorbiaceae & 8 & 26.71 & 50.88 \\
\hline Macaranga tanarius & Euphorbiaceae & 54 & 25.83 & 50.88 \\
\hline Artocarpus odoratissimus & Moraceae & 21 & 24.42 & 50.88 \\
\hline Artocarpus tamaran & Moraceae & 8 & 22.90 & 50.88 \\
\hline Artocarpus integer & Moraceae & 17 & 22.90 & 50.88 \\
\hline Vernonia arborea & Asteraceae & 17 & 22.90 & 50.88 \\
\hline Glochidion obscurum & Phyllanthaceae & 4 & 22.90 & 50.88 \\
\hline Mangifera sp. & Anacardiaceae & 4 & 22.90 & 50.88 \\
\hline Mangifera indica & Anacardiaceae & 17 & 20.99 & 50.88 \\
\hline Total & & 801 & $3,198.52$ & $5,786.97$ \\
\hline
\end{tabular}




\section{Logging cost}

The logging cost of Eusideroxylon zwageri species was higher than that of the other spesies in this research (Table 7). However, logging cost per hectare was determined by log volume, and this research found difference in logging cost per hectare among trees species. The total logging cost in abandoned land in this research (USD752.54 ha-1) was lower compared to that in another research (USD1,212.24 $\mathrm{ha}^{-1}$ ) (Karmini et al. 2020). This is relevant because the total log volume in abandoned land in this research location was $76.86 \mathrm{~m}^{3} \mathrm{ha}^{-1}$ (Table 3), lower than that in another research location, i.e., $91.97 \mathrm{~m}^{3} \mathrm{ha}^{-1}$ (Karmini et al. 2020).

\section{Profit margin}

The 3 trees species contributing big profit margin were Eusideroxylon zwageri, Alstonia scholaris, and Artocarpus anisophyllus. Those species also had high log and wood prices. This mean prices of buying and selling determine profit in marketing both $\log$ and wood. Data in Table 8 present profit margin of selling 29 trees species from abandoned land.

\section{Stumpage value}

The total stumpage value at the abandoned land was estimated as much as USD1,495.31 $\mathrm{ha}^{-1}$. There were 29 trees species and each species contributed an average of USD51.56 ha- ${ }^{-1}$. The highest stumpage value was from Artocarpus anisophyllus, i.e., USD168.97 $\mathrm{ha}^{-1}$ and the lowest one Mangifera odorata, i.e., USD2.29 ha ${ }^{-1}$ (Figure 4).

Table 8. Profit margin

\begin{tabular}{|c|c|c|c|c|c|c|c|}
\hline \multirow{2}{*}{ Species } & \multirow{2}{*}{ Family } & \multicolumn{2}{|c|}{ Logging cost } & \multirow{2}{*}{ Species } & \multirow{2}{*}{ Family } & \multicolumn{2}{|c|}{ Profit margin } \\
\hline & & $\left(\right.$ USD ha $\left.^{-1}\right)$ & $\left(\right.$ USD $\left.^{-3}\right)$ & & & $\left(\mathrm{USDm}^{-3} \mathrm{ha}^{-1}\right)$ & $\left(\mathrm{USDm}^{-3}\right)$ \\
\hline Eusideroxylon zwageri & Lauraceae & 7.51 & 101.76 & Eusideroxylon zwageri & Lauraceae & 626.24 & 150.30 \\
\hline Artocarpus integer & Moraceae & 83.25 & 67.84 & Alstonia scholaris & Apocynaceae & 469.68 & 112.72 \\
\hline Artocarpus tamaran & Moraceae & 74.43 & 67.84 & Artocarpus anisophyllus & Moraceae & 430.54 & 103.33 \\
\hline Mangifera indica & Anacardiaceae & 61.13 & 67.84 & Oroxylum indicum & Bignoniaceae & 410.97 & 98.63 \\
\hline Artocarpus dadah & Moraceae & 57.68 & 67.84 & Durio zibethinus & Malvaceae & 145.55 & 34.93 \\
\hline Glochidion obscurum & Phyllanthaceae & 54.70 & 67.84 & Cratoxylum arborescens & Hypericaceae & 125.57 & 30.14 \\
\hline Vernonia arborea & Asteraceae & 41.96 & 67.84 & Artocarpus heterophyllus & Moraceae & 117.42 & 28.18 \\
\hline Artocarpus odoratissimus & Moraceae & 34.25 & 67.84 & Archidendron pauciflorum & Fabaceae & & 18.32 \\
\hline Macaranga gigantea & Euphorbiaceae & 33.42 & 67.84 & Artocarpus elasticus & Morac & & 17.26 \\
\hline Nephelium lappaceum & Sapindaceae & 30.83 & 67.8 & Nephelium lappaceum & Sapindaceae & & 14.79 \\
\hline Homalanthus populneus & Euphorbiaceae & 30.55 & 67.8 & Artocarpus dadah & Moraceae & & 14.79 \\
\hline Artocarpus anisophyllus & Moraceae & 27. & & aurea parvifolia & Phyll & & 12.68 \\
\hline Mangifera $\mathrm{sp.}$ & Anacardiaceae & 23. & & Iangifera odorata & Anacardiaceae & & 7.05 \\
\hline Macaranga tanarius & Euphorbiaceae & 23.29 & & Macaranga triloba & Euphorbiaceae & 29. & 7.01 \\
\hline Durio zibethinus & Malvaceae & 23.22 & 67. & Ficus uncinata & Morac & 28. & 6.94 \\
\hline orientalis & Cann & 21.35 & 67. & Mallotus paniculatus & Euph & & 6.81 \\
\hline arvifolia & Phyllanthaceae & 21.01 & 67.84 & Homalanthus populneus & Euphorbiaceae & 27. & 6.54 \\
\hline Artocarpus elasticus & Moraceae & 20.02 & 67.84 & Symplocos fasciculata & Symplocaceae & 26. & 6.34 \\
\hline Symplocos fasciculata & Symplocaceae & 19.38 & 67.84 & Trema orientalis & Cannabacea & 25.69 & 6.16 \\
\hline Cratoxylum arborescens & Hypericaceae & 12.23 & 67.84 & Couroupita guianensis & Lecyt & 25.69 & 6.16 \\
\hline Oroxylum indicum & Bignoniaceae & 11.75 & 67.84 & Macaranga gigantea & Euphorbiaceae & 25.69 & 6.16 \\
\hline Couroupita guianensis & Lecythidaceae & 10.18 & 67.84 & Macaranga tanarius & Euphorbiaceae & 24.84 & 5.96 \\
\hline Artocarpus heterophyllus & Moraceae & 6.32 & 67.84 & Artocarpus odoratissimus & Moraceae & 23.48 & 5.64 \\
\hline Mallotus paniculatus & Euphorbiaceae & 5.73 & 67.84 & Artocarpus tamaran & Moraceae & 22.02 & 5.28 \\
\hline Ficus uncinata & Moraceae & 4.59 & 67.84 & Artocarpus integer & Moraceae & 22.02 & 5.28 \\
\hline Archidendron pauciflorum & Fabaceae & 4.45 & 67.84 & Vernonia arborea & Asteraceae & 22.02 & 5.28 \\
\hline Macaranga triloba & Euphorbiaceae & 4.39 & 67.84 & Glochidion obscurum & Phyllanthaceae & 22.02 & 5.28 \\
\hline Alstonia scholaris & Apocynaceae & 2.38 & 67.84 & Mangifera sp. & Anacardiaceae & 22.02 & 5.28 \\
\hline Mangifera odorata & Anacardiaceae & 1.48 & 67.84 & Mangifera indica & Anacardiaceae & 20.18 & 4.84 \\
\hline Total & & 752.54 & $2,001.36$ & Total & & $3,075.50$ & 738.12 \\
\hline Mean & & 25.95 & 69.01 & Mean & & 106.05 & 25.45 \\
\hline
\end{tabular}




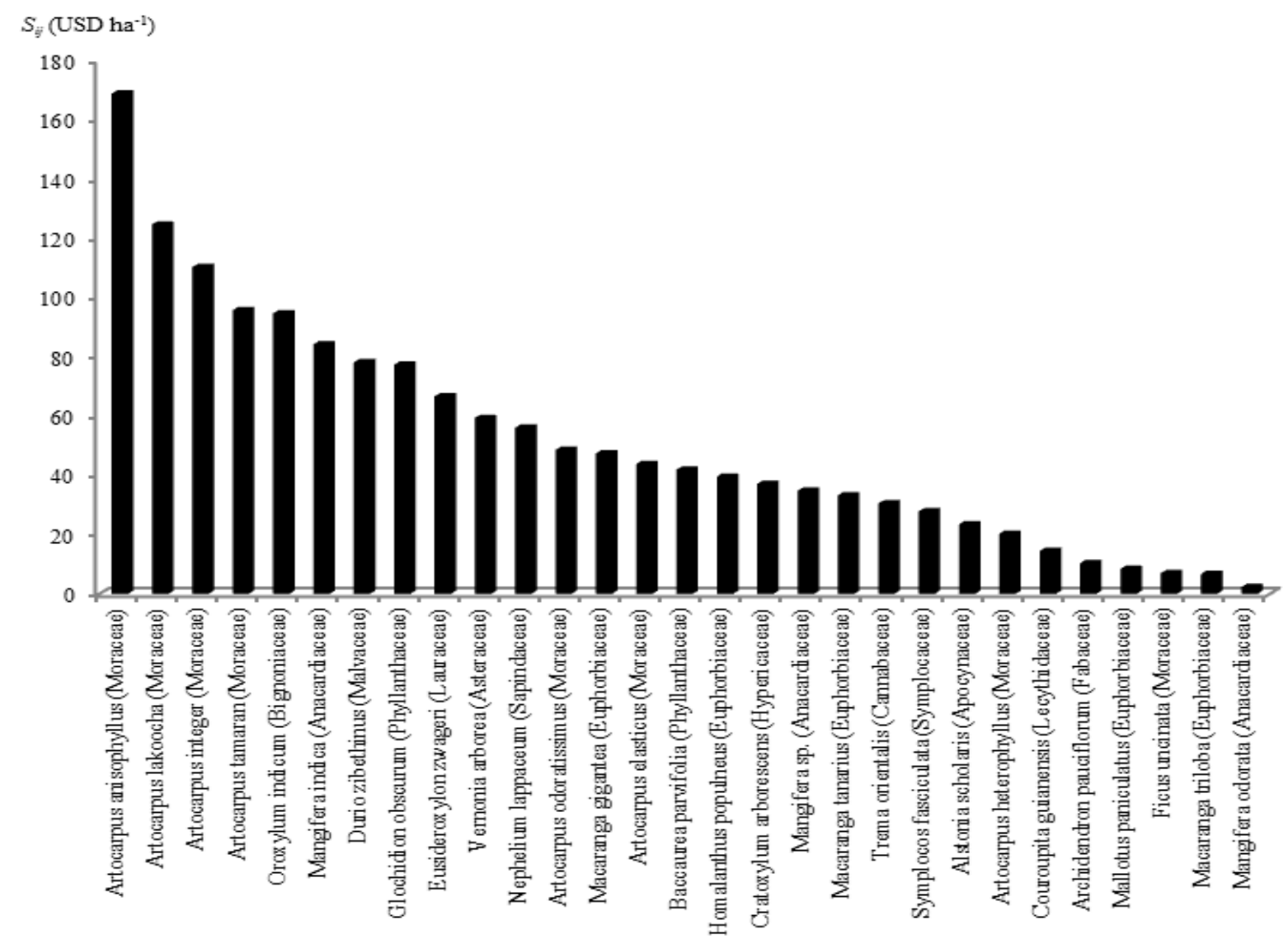

Figure 4. Stumpage value of trees at abandoned land

\section{ACKNOWLEDGEMENTS}

We would like to express our gratitude to the Ministry of Education and Culture, the Republic of Indonesia for the financial support for this research through the scheme of Hibah Penelitian Dasar Unggulan Perguruan Tinggi Contract No.: 183/SP2H/AMD/LT/DRPM/2020.

\section{REFERENCES}

Álvarez-Yépiz JC, Martínez-Yrízar A, Búrquez A, Lindquist C. 2008. Variation in vegetation structure and soil properties related to land use history of old-growth and secondary tropical dry forests in Northwestern Mexico. For Ecol Manage 256: 355-366. DOI 10.1016/j.foreco.2008.04.049

Aththorick TA, Setiadi D, Purwanto Y, Guhardja Y. 2012. Vegetation stands structure and aboveground biomass after the shifting cultivation practices of Karo People in Leuser Ecosystem, North Sumatra. Biodiversitas 13 (2): 92-97. DOI: 10.13057/biodiv/d130207

Brower JE, Zar JH, Von Ende CN. 1990. Field and Laboratory Methods for General Ecology, $3^{\text {rd }}$ Ed. Wm. C. Brown Publishers, USA.

Fachrul MF. 2007. Metode Sampling Bioekologi. Bumi Aksara, Jakarta. [Indonesian]

Feldpausch TR, Prates-Clark CC, Fernandes ECM, Riha SJ. 2007. Secondary forest growth deviation from chronosequence predictions in Central Amazonia. Global Change Biol 13: 967-979. DOI: 10.1111/j.1365-2486.2007.01344.x

FDPM. 1997. Manual Kerja Luar Sistem Pengurusan Memilih. Forestry Department of Peninsular Malaysia, Kuala Lumpur. [Malaysian]
Hanum IF, Pius P, Noor AAG. 2001. Economic valuation of tree species diversity at Ayer Hitam Forest, Selangor, Peninsular Malaysia. Petranika J Trop Agric Sci 22 (2): 167-170.

Husch B, Miller CI, Beers TW. 1982. Forest Mensuration. John Wiley and Sons Publishing, New York.

Karmini, Karyati, Widiati KY. 2020. The role of tropical abandoned land relative to ecological and economic aspects. For Soc 4 (1): 181-194. DOI: $10.24259 /$ fs.v4i1.8939

Karyati, Ipor IB, Jusoh I, Wasli ME, Seman IA. 2013. Composition and diversity of plant seedlings and saplings at early secondary succession of fallow lands in Sabal, Sarawak. Acta Biologica Malaysiana 2 (3): 85-94. DOI: $10.7593 / \mathrm{abm} / 2.3 .85$

Karyati, Ipor IB, Jusoh I, Wasli ME. 2018. Tree stand floristic dynamics in secondary forests of different ages in Sarawak, Malaysia. Biodiversitas 19 (3): 687-693. DOI: 10.13057/biodiv/d190302

Klanderud K, Mbolatiana HZH, Vololomboahangy MN, Radimbison MA, Roger E, Totland O, Rajeriarison C. 2010. Recovery of plant species richness and composition after slash-and-burn agriculture in a tropical rainforest in Madagascar. Biodivers Conserv 19:187-204. DOI: $10.1007 / \mathrm{s} 10531-009-9714-3$

Krebs CJ. 2001. Ecology, 5th Ed. Addison Wesley Longman Inc., USA.

Kusmana C. 2017. Metode Survey dan Interpretasi Data Vegetasi. IPB Press, Bogor. [Indonesian]

Noor AGA, Vincent JR, Yusuf H. 1992. Comparative Economic Analysis of Forest Revenue System in Peninsular Malaysia. Osborn Center Forestry Policy Grants Program Final Report, USA.

Noor AGA, Shahwahid MHO. 1999. Price-Based Valuation Method: Stumpage Appraisal of Timber Resources Peat Swamp Forest. Manual on Economic Valuation of Environmental Goods and Services of Peat Swamp Forests. Forestry Department of Peninsular Malaysia, Kuala Lumpur.

Odum EP, Barrett GW. 2005. Fundamentals of Ecology, 5th Ed. Thomson Brooks/Cole, Belmont, CA. 
Ohtsuka T. 1999. Early stages of secondary succession on abandoned cropland in north-east Borneo island. Ecol Res 14: 281-290. DOI: 10.1046/j.1440- 1703.1999.143304.x

Setiawan AD. 2010. Review: Biodiversity conservation strategy in a native perspective; case study of shifting cultivation at the Dayaks of Kalimantan. Nusantara Biosci 2 (2): 97-108. DOI: $10.13057 /$ nusbiosci/n020208
Yirdaw E, Monge AM, Austin A, Toure I 2019. Recovery of foristic diversity, composition and structure of regrowth forests on fallow lands: implications for conservation and restoration of degraded forest lands in Laos. New Forests 50: 1007-1026. DOI: 10.1007/s11056019-09711-2. 